\title{
3A BOJHATA
}

\section{Кратка содржина}

Безбедносните студии не можат да ги заобиколат војната и процесот на војуване. Дебатите за изменетата природа на војната се стари колку и самиот поим за војна. Авторот ги поставува прашаньта: Дали е и понаталу релевантен Клаузевиц со еволуираниот концепт за бојно поле?!; Каков е придонесот на нарациите за политичко насилство и тероризам во процесот на воената мобилизациија?!; Дали и како можеме да ја проучуваме модерната војна преку призмаmа на културата?!; и Дали војната сѐ уште постои во очите на меѓународното право?! Во анализата за војната кога се користи примарното тројство (на Клаузевиц) како аналитичка рамка, станува очигледно дека теоријата на Клаузевиц, за војната е доволно широка и флуидна за да го опфати цзелиот воен спектар, вклучително и нерегуларните недржавни конфликти. Концептот на наратив може да придонесе за теоријата и истражуването на феномените на тероризам, политичко насилство и радикализација. Истражуването на тековната значајност на концептот на војна вклучува прашана од суштинска важност за забраната за закана за употреба на сила или употребата на сила во член 2(4) од Повелбата во време на засилена волја за употреба на сила како инструлент на надворешната политика. Остануваат неодоворени прашаньта за тотална војна, за врската меѓу војната и глобализацијата и промените во војуването кај напредните индустриски демократии на Запад.

Клучни зборови: ВОЈНА, ВОЈУВАЮЕ, ФИИОЗОФИЈА, ПОЛИТИКА, КИАУЗЕВИЦ

\section{Вовед}

Војувањето може да се разгледува на многу начини. Војната е феномен кој предизвикува многу страдање, но од друга страна истата таа војна ги забрзува технолошките пронајдоци и секогаш била катализатор на општествени и политички реформи. Иако сметана за зло, таа понекогаш е нужна, во ситуација доколку се гледа низ перспектива на она што ОН го нарекуваат наметнување на „меѓународен мир и безбедност“. Потребата за проучување на војната во одредени случаи е поттикната од пристрасноста да ѝ се помогне на сопствената страна да ја добие војната, а во други случаи пристапот кон неа е како со медицинскиот пристап кон болестите според кој тие треба да се проучуваат за да може да се искоренат. Без огдед на мо- 
тивацијата за нејзино проучување, основата на изучувањето е загриженоста од војната. Особено трендовите на вдијанието врз цивилите и можноста за употреба на оружје за масовно уништување се потсетник дека војувањето останува да биде важен извор на несигурност во светот.

Се поставува прашањето за преиспитување на поимот за војна и некои од главните обележја на вооружениот конфликт по завршувањето на Втората светска војна. Денес е генерално чувството дека заканата од голема војна помеѓу големите сили е намалена по Студената војна, но, сепак во светот во некои делови сѐ уште се војува а како една од причините за преиспитувањето на војната е и обидот да се надминат наследствата од минатото. Иако во последно време е намален бројот и интензитетот на војните, сепак и понатаму се трошат многу пари за развој на вооружените системи со цел да се победи во идна евентуална војна. Така на пример во 2005 година Владата на САД само за војната во Ирак трошела околу 8 милијарди долари месечно (ICG 2006, 32), а според Институтот за меѓународно истражување на мирот од Стокхолм проценето е дека во 2005 година вкупната светска потрошувачка достигнала 1.118 милијарди долари. Особено во неразвиените земји војната и понатаму е главниот извор на небезбедност. Преиспитување на феноменот на војната може да се направи прво преку анализа на трите главни филозофии за војната и објаснување каков е пристапот кон поимот за војна во современите безбедносни студии, односно испитување на начините за разбирање на улогата на војната во светската политика.

\section{1. Филозофии на војната}

Повеќето мислители за општеството не биле во можност да го сфатат огромниот проблем што војната го претставува за нашето разбирање на општеството воопшто: тие го маргинализираат, го третираат како исклучителен, абнормален итн. Од просветителството па до Диркем, повеќето најголеми социолози ја изоставуваат војната од нивната централна проблематика. Како резултат на тоа, работата во социологијата на војната нема интегриран фокус. Сепак, недостатокот на кохерентна, интегративна рамка не го запрела научното творештво за војната. Новиот интерес за војната генерирал корпус на пишани трудови, честопати истуран заедно под насловот „социодогија на војната и војската“ што е многу разновиден (Kurtz, 1992). Тој се движи од макроисториски аргументи за важноста на војната како фактор во општествените промени (Marwick 1974; Smith, H. 1986) до студии за влијанието на војната врз цивилното население. Историосоциолозите го истражувале влијанието на војната врз револуцијата (Adelman 1985), градење држава (Mann 1986), индустриски конфликт и демократија (Downing 1992), меѓу другото. Сите овие, и повеќе, се референтни објекти на истрага за социологија на војната.

Познатиот пруски воен теоретичар и познат филозоф на војната, Карл Фон Клаузевиц (1780 - 1831), во своето капитално дело „За војната“, 
дава основна дефиниција за војната и логички анадизира како еден чин како што е војувањето може суштински да влијае на природата на општествените настани. Клаузевиц не е убеден дека воените кампањи од раздични историски епохи може да се проучуваат како „лекции“ за сегашноста. Напротив, Клаузевиц (1976, 586-93) ги препознава променливите интеракции на општеството и војската кои доведуваат до сосема раздични начини на водење војна. Клаузевиц ја објавува својата намера да изврши ревизија на „За војната“ врз основа на две водечки идеи: прво, дека постојат два вида на војна: сеопфатна војна и ограничена војна; и второ, дека војната е продолжување на политиката со други средства. Тој го трансформираше, но не го напушта стариот воен поглед и прибегнува кон комплетно нови теоретски видувања (Gat, 1989, 199). Клаузевиц верувал дека ја надминал оваа противречност, помеѓу дефинирање на војната во смисла на неограничено насилство и дефинирањето на војната како продолжување на политиката со воведување на концептот на апсолутна војна. Понатаму, може да се развие и модифицира оваа основна рамка согласно ставот дека социјалната организација на актерите има определувачка улога во предвидувањата на воените влогови.

Надоврзувајќи се на ова и коментирајќи го влијанието на војната врз политиката и општеството пошироко, Анатол Рапопорт (1968, 12 - 13) истакнува дека треба да ги истражуваме начините на кои прифаќањето или одбивањето одредена филозофија за војната може да вдијае врз улогата на војната врз секојдневните човекови работи и толку длабоко да ги погоди нашите животи. Така, Рапопорт класифицира три вида филозофии за војната: политички, есхатолошки и катаклизмични.

\section{Политичка филозофија на војната}

Клаузевиц ја застапувал политичката филозофија на војната, со познатата дефиниција за војната како чин на насилство чија цел е да го принуди противникот да ја исполни нашата волја или како „војната продолжена рака на политиката“. „Војната е акт на сила да го принудиме нашиот непријател да ја изврши нашата волја... и нема логично ограничување на примената на таа сила“ (1976: 75-7). „Борбените сили мора да бидат уништени: т.е. мора да се доведат до таква состојба што повеќе не можат да ја водат борбата ... земјата мора да биде окупирана... Сепак, и двете работи може да се направат и војната не може да се смета дека завршила сѐ додека волјата на непријателот не е скршена... (1976: 90)“. Сумирано: од сите можни цели во војната, уништувањето на силите на вооружените непријатели секогаш се појавува како највисоко (1976: 99). Во неговите подоцнежни ревизии на текстот, Клаузевиц дава втор, радикално поинаков, одговор, многу цитиран поим дека војната е продолжување на политиката со други средства: Војната не е ништо друго освен продолжување на подитиката со други средства (1976: 60). Војната не е само чин на подитика, туку и вистински подитички инструмент, продолжение на подитичкиот 
однос, спроведен со други средства... Подитичката цел е намерата, војната е само средство за достигнување до неа, и средствата никогаш не може да се сметаат изолирани од нивната цел. Додека идејата дека војната е продолжение на политиката беше водечка насока за неговата зрела анализа за природата на војната, Клаузевиц исто така пишува дека тоа војување било сложена комбинација на страст, шанса и разум. Првиот од овие три елементи главно се однесува на луѓето; вториот на командантот и неговата војска; третиот на владата, при што подитичките цели се деловно работење само на владата. До степен до кој војната беше продолжение на политиката, таа беше рационална, намерна активност насочена кон промена на однесувањето на противникот.

Според ваквата филозофија, војната претставува рационално средство за постигнување национална цел, односно војната е рационална, инструментална и национална. Одлуката за војна се донесува врз основа на разумна проценка на националните политички авторитети согласно визионираната цел. Во времето на Клаузевиц, политичките авторитети се претставени преку суверените држави, а војната била сметана за легитимно средство на државната политика кое ќе се користи само со јасна цел. Кога Клаузевиц вели дека војната е продолжение на политиката тој треба да биде протолкуван дека војната е продолжение на надворешната политика во политички системи кои се доминирани од елитите. Со доаѓањето на масовната демократија значењето на диктумот дека војната е продолжение на политиката претрпел значајна промена. Веќе не беше едноставно рационалното извршување на државни вештини од страна на елитите, и стана посложен и дијалектички процес. Победата во пракса со таков рационален политички инструмент ја добивале оние кои биле највешти во уметноста на маневрирање и уништување.

\section{Есхатолочка филозофија на војната}

Есхатолошката филозофија се врти околу „идејата дека историјата, или дел од неа, ќе кулминира со конечна војна, што ќе доведе до остварување на некој огромен план - божествен, природен или човечки“ (Рапопорт 1968: 15). Есхатолошката школа на мисла смета дека сите војни (или сите поголеми војни) водат кон некаква цел и тврди дека некој конечен конфликт некогаш ќе го реши патот следен од сите војни и ќе резултира со масовен пресврт на општеството и последователно создавање ново општество ослободено од војна (во раздични теории, општеството што произлегува може да биде или утопија или дистопија). Оваа филозофија се јавува во две варијанти: месијанска и глобална.

Во месијанската варијанта се претпоставува дека актерот кој е одреден да го спроведе големиот план веќе постои (дошол). Неговата мисија е да наметне праведен мир во светот, елиминирајки ја војната во иднината. Месијанската есхатолошка филозофија е изведена од еврејско-христијанскиот 
концепт за месија и смета дека војните кулминираат со обединување на човештвото под единствена вера или единствен владетел. ${ }^{1}$

Глобалната варијанта, претпоставува дека големиот план ќе се оствари во хаосот на конечната војна. Во христијанската есхатологија тоа е христијанскиот концепт за војната Армагедон која подразбира сили кои се собрани околу Христос во неговото второто доаѓање и конечниот пораз на сатаната (но истовремено може да потпадне и под Месијанската теорија). Марксистичкиот концепт на комунистички свет, управуван од пролетаријатот по последната светска револуција, е пример за глобалната теорија. Во комунистичката есхатологија борбата за моќ е помеѓу класите а не помеѓу државите или религиите. Настанокот на светскиот пролетеријат требаше да ја промени империјалистичката војна во класна војна и по поразот на буржоазијата да се воспостави светски ред во кој повеќе ќе нема војни.

\section{Катаклизмичка филозофија на војната}

Катаклизмичката филозофија ја смета војната за „катастрофа која ќе ја погоди целата човечка раса или еден нејзин дел“ (Рапопорт 1968, 16). Според тоа, војната е Божја казна или несреќен ефект на еден анархичен меѓуннароден систем. И оваа филозофија се јавува во две варијанти: етноцентрична и глобална.

Првата поткатегорија на катаклизмичката филозофија на мисли е етноцентричната катаклизма, во која ова гледиште е фокусирано конкретно на маките на одредена етничка припадност или нација. Во етноцентричната верзија војната е нешто што најверојатно ќе нѐ снајде, односно војната е нешто со што другите ни се закануваат дека ќе ни го сторат нам. Веројатната, престојна војна не е во наша полза, и единствено што може да направиме да го спречиме огромното уништување или да ги олесниме најлошите последици².

Во глобалната варијанта војната е катаклизма која ќе го зафати целокупното човештво, а не само одредена група луѓе. Тука, никој не е одговорен но, и никој нема полза од таа катастрофа. Според оваа филозофија, вниманието е насочено на спречување на војната, „на откривање на причините за војна и на откривање на инструменталните методи за решавање конфликти“ (Рапопорт 1968: 40). Катакдизмичката школа на мислата, која беше поддржана од Лав Толстој во неговиот епски роман „Војна и мир“, ја гледа војната како забрана за човештвото - без оглед дали е избеглива или неизбежна - и не служи за ништо друго освен да предизвика уништување

\footnotetext{
${ }^{1}$ Примери за оваа филозофија ги вклучуваат обидите на крстоносците за обединување на светот во една вера во средниот век, нацистичката доктрина за суперраса или визијата на Ал каеда и ИСИС за глобален калифат како и американскиот концепт од 19 век за Судбинскиот манифест.

${ }^{2}$ На пример гледиштето во јудаизмот за војната како казна од Бога врз Израелците во одредени списи од Тенах (Стариот завет).
} 
и страдање и што може да предизвика драстични промени на општеството, но не во каква било телеолошка смисла. Ставот на Толстој може да биде ставен во поткатегоријата глобална катакдизмичка филозофија на војната.

Како што Тенах (во одредени делови) ја гледа војната како неизбежен чин на Бога, така Толстој особено ја нагласува војната како нешто што го снаоѓ човекот и на никаков начин не е под вдијание на човековата „слободна волја“, туку е резултат на неспротивставдива глобална сила.

Тодкувано според овие описи, во политичката филозофија војната е споредена како стратегиска игра (како шах), во есхатолошката смисла со мисијата или расплетот на драмата а во катаклизматичката смисла со стихиен пожар или епидемија3

\section{2. Оспорување на филозофијата на Кдаузевиц?!}

Историски, од ерата на Наполеон па сѐ до Првата светска војна европската политика овозможувала прекрасни услови за процут и доминација на политичката филозофија на Клаузевиц. До времето кога европските големи сили заглавиле во рововите на Првата светска војна станува јасно дека развојот на воената технологија го потврдува сознанието дека методите на Клаузевиц се многу скапи, а уметноста на маневрирање - скоро невозможна. Индустријализираната касапница на Големата војна престана да им служи на политичките цели на двете страни. Затоа есхатолошката и катаклизамичката филозофија добија на важност.

Денес, политичката филозофија на Клаузевиц е пред голем предизвик. Дебатата е засилена околу степенот до кој размислувањата на Клаузевиц сѐ уште се релевантни. Во оспорувањето на релевантноста на политичката филозофија на Клаузевиц ги истакнуваме следниве ставови:

А) Според Мартин Ван Кривелд: „Современата стратешка мисла... е погрешна и втемелена во сликата на Клаузевиц, која е или непотребна или погрешна. Влегуваме во ера... на војување меѓу етнички и религиски групи... Во иднина војната нема да ја водат армии, туку групи кои ние ги нарекуваме терористи, герилци, бандити, крадци, но кои ќе се стремат кон многу повисоки позиции за да се опишат себеси. Нивните организации ќе бидат создадени по харизматичка, а не институциска линија, лојалност на идеолошка база... Ако конфликтот со низок интензитет е навистина бран за во иднината, тогаш стратегијата во класична смисла ќе исчезне“ (Van Creveld 1991, 197, 207).

\footnotetext{
${ }^{3}$ Овие, гледишта се разбира, не ги исцрпуваат ставовите за војната што владее во различни периоди и на различни места. На пример, на војната на моменти се гледало како на забава или авантура, како единствено правилно занимање за еден благородник, како афера на честа (на пример, деновите на витештвото), како церемонија (на пр. меѓу Ацтеките), како излив на агресивни инстинкти или манифестација на „смртна желба“, како начин на природата да се обезбеди опстанок на најприспособените, како апсурд (на пр. кај Ескимите), како жилав обичај кој е предодреден да изумре како ропството и како кривично дело.
} 
Б) Во 1996 година, Делберт Тиесен коментира дека „Војната во Персискиот Залив е можеби последната Клаузевиц војна која се водела“ (Shimko 2010, 22). Тиесен не е единствениот професор што предвидувал војна во која диктумот на Клаузевиц има мала важност. Некои од најистакнатите писатели во стратешките и безбедносните студии објавиле анализи за карактерот на современото војување што ја земаат како почетна точка опаѓачката важност на Клаузевициевата теорија (Handel 2008; Schuurman 2010; Williams 2013; Strachan 2014; Lonsdale 2016). Мартин ван Кревелд (1991), на пример, гледа на трендот во глобалното војување кон неправилност и асиметрија како знак на застареност на теоријата на Клаузевиц, тврдејќ́ дека „,[ако] конфдиктот со слаб интензитет е бран на иднината, тогаш стратегијата во неговата класична смисла ќе исчезне“ (стр. 207). Во иста насока, Мери Калдор го негира Клаузевиц со тврдењето дека државите го изгубиле својот примат во војната и наместо тоа биле заменети со групи кои се идентификуваат врз основа на религија или етничка припадност (Caldor 2007; Schuurman 2010). Ваквата критика, сепак, се заснова на фундаментално погрешно читање на теоријата на Клаузевиц за војната и филозофската рамка во која е поставена.

Генерално, неколку настани отворено ја поткопаа силата на политичката филозофија на војна.

Прво, концептот за бојно поле, клучен за сфаќањето на Клаузевиц, исчезна. Бојно поле, боен простор или поле на битка е локација на сегашна или историска битка што вклучува воено војување. Генерално се сфаќа дека е ограничено на точката на контакт меѓ спротивставените сиди, иако битките може да вкдучуваат војници кои покриваат широки географски области. Современата воена теорија и доктрина, со технолошкиот напредок во војувањето, го еволуираа разбирањето на бојното поле од тоа дефинирано со теренот па сѐ до повеќеслојна перцепција на сите фактори што влијаат на водењето на битката и се конципира како борбен простор.

Историски гледано, воените сиди понекогаш тренираде користејќи методи погодни за израмнето бојно поде, но не и за теренот во кој најверојатно завршиле во борби. Колку и да е сменета технологијата, теренот сѐ уште не може да се игнорира, бидејќи тоа не само што вдијае на движењето на бојното поле, туку и движењето до и од него, а догистиката е критична. Бојното поле, во индустриското време, може да биде железничка линија или автопат. Како што технологијата станува сѐ пософистицирана, должината на „опашката“, од која зависат трупите на фронтот, станува сѐ подолга, а со тоа расте и бројот на места на кои може да се реши битката (надвор од непосредната точка на контакт).

Нападите од 11 септември 2001 година, покажаа дека денес реони за напад може да бидат и западните градови и обратно, војната на САД против терор - преименувана како долга војна - го разбира бојното поле како целата планета. Во иднина битките најверојатно нема да се ограничат на планетата Земја, а САД поконкретно (покрај Русија, Кина и др.) ќе бидат 
принудени да ја вооружуваат вселената за да ги заштитат сателитите од кои зависат комуникациските и информациските системи (Hirst, 2002). Зголемената урбанизација и потребата на антизападните сили за прикривање доведоа до борби во многу урбани области, како што се индустриските градови, сиромашни предградија, па дури и бегалски кампови (Hills, 2004). Водењето воени операции во урбаните области поставува бројни предизвици поради зголемената интерактивност во однос на другите простори како што се џунгдите и пустините.

Второ, самите јавни изјави на водачите на двете спротивставени страни од војната со/против терор, Осма бин Ладен и Џорџ В. Буш, ја одбегнуваат политичката нарација на војување. Тие отворено ги прифатија есхатолошките филозофии во своите повикувања на глобален џихад и на праведна војна против здото.

Вообичаено конструкцијата на наративот е поврзана со прашања во врска со социјалната и политичката моќ. Но е многу повеќе во случајов со наративите за Доброто и Злото како метод на убедување низ идентификација на дијалектички однос помеѓу терористичката комуникација на Исламска Држава (ИСИС) и контратерористичката реторика на западните влади како рефлектирани во владините извештаи, изјави, говори и аудио-визуелен материјал. Концептот на наратив може да придонесе за теоријата и истражувањето на феномените на тероризам, политичко насилство и радикализација, нудејќи нови средства за понатамошен развој на клучните конструкции како што се идентитетот, емоциите и културата (Pemberton and Aarten 2017,2).

Третиот проблем за застапниците на политичката филозофија и еден од оние со кои Клаузевиц никогаш не се соочи е војната која вклучува размена на нуклеарно оружје. Нуклеарното оружје е дизајнирано да ги спречува и обесхрабрува потенцијалните противници. Вообичаено се сметаше дека иако нуклеарното оружје не е способно да донесе разумни значајни воени ефекти, тоа е сепак искдучително способно да создаде политички ефекти. Аргументите за голема нуклеарна сила немаат значење освен ако не се поврзани со стратегија за контрасила или со ризични гаранции дека генерално, храбрите лидери преземаат ризици што вообичаено не би ги презеле доколку би постапувале самостојно. Бавното, стабилно ширење на нуклеарно оружје веројатно ќе продолжи. Но, во случајов со војната на Клаузевиц, употребата на нуклеарното оружје ја раскинува релацијата на војна (нуклеарна) и разумна државна активност.

Последно, при соочување со револуционерна војна, која повикува на контрареволуционерни одговори, почитувањето на советот на Клаузевиц да не се уништуваат непотребно воените сили на противникот, станува проблематично не само затоа што тие сили не се распознаваат помеѓу локалното население, туку и поради тоа што никогаш не постои сигурност дека тие сили се елиминирани „освен ако не сме подготвени да уништиме еден добар дел од населението“" (Rapoport, 1968, 53). Овој обид да се осигура 
незначајноста на револуционерната идеологија која е во прашање, проблематично се судира со политичката цел на војната, односно го прекршува основното правило на Клаузевиц дека војната е продолжената рака на политиката.

При разгледувањето на литературата на оние научници кои сакаат да ги отфрлат ставовите на Клаузевиц како несоодветни за модерната војна, станува очигледно дека нивната критика го претставува погрешно размислувањето на Клаузевиц на два фундаментални начина: претпоставува (1) дека теоријата на Клаузевиц за војната е државноцентрична, и (2) што промените во начините на војување се еднакви на промените во природата на војната (т.е. војување за раздика од војната). Двете се лажни и најверојатно се базираат на погрешно читање „За војната“ на Клаузевиц.

Погледот на клаузевициското тројство како (1) народ, (2) војска и (3) влада насочува кон инхерентно државно-центричен поглед на војната - став кој се сместил во највисоките ешалони на војската (и академско) размислување. Ова толкување, сепак, се заснова на таканареченото секундарно mројство, кое Клаузевиц го користел како обична илустрација на функциите на поважното, но сепак хронично занемарено, примарно тројство. Примарното тројство се обидува да ја долови природата на војната како широк феномен во парадоксалниот, но целосно меѓусебно поврзан спектар. Со зборовите на Клаузевиц $(1976,89)$ војната е вистински камелеон кој ги приспособува своите карактеристики на дадениот случај. Како тотален феномен, неговите доминантни склоности секогаш ја прават војната парадоксално тројство - составено од исконско насилство, омраза и непријателство, кои треба да се сметаат за слепа природна сила; на играта на среќа и веројатност во рамките на кои креативниот дух е слободен да лута; и на неговиот елемент на подреденост, како инструмент на подитика, што го прави предмет само на разумот.

Најгласните критичари на Клаузевиц го земале неговото секундарно тројство да биде во основата на она што мора да биде целосно државно-центрична теорија за војната. Мартин ван Кревелд, најзначајно, ја идентификува теоријата на Клаузевиц дека се базира целосно на секундарното тројство, а со тоа и на државата, нарекувајќи го концептот тринитарна војна пред да го прогласи за нематеријален (Ван Кревелд 1991). Но, така како што пишува, овие тесни толкувања му штетат на Клаузевиц, чие дело е далеку поинверзално. Кога се зема примарното тројство како рамка, типот на актер - државен, недржавен, племенски - станува прашање од второстепено значење (Smith, 2005), бидејќи примарното тројство на Клаузевиц не подразбира ништо за социоподитичката природа на субјектот што води војна, затоа што во основа, сите актери во војната се предмет на насилство, случајност и рационална цел. Поинаку кажано, бидејќи примарното тројство на Клаузевиц се фокусира на основните, нематеријални аспекти на војната како широк феномен, материјалните размислувања, како што е типот на актерот, не влијаат на применливоста на рамката (Lonsdale, 2016). 
Затоа војните со недржавните актери, кои имаат племенски или секташки карактер, сѐ уште спаѓаат под чадорот на теоријата за војна на Клаузевиц.

Друга критика доаѓа од новата воена школа за размислување, која тврди дека денешните случувања во воените работи рефлектираат фундаментални промени во природата на војувањето што претставува раскин со стариот концепт на Клаузевиц. Светот по Студената војна бележи поместување од меѓудржавната војна кон внатрекомунално насилство и нередовни конфронтации, како и огромен технолошки напредок. Проблемот на погрешното разбирање на Клаузевиц во овој случај доаѓа од класифицирање на герилските методи и војувањето со мал интензитет како обична тактика во војната, а не како посебни категории на војна. Второ, технолошките промени не влијаат на природата на војната, колку што вдијаат на контекстот на војната. Овие две точки на промена, нерегуларноста на конфликтот и технолошкиот напредок, според тоа, не ја допираат природата на војната, туку вечно менливиот карактер на војувањето. Поборниците на новата школа за размислување за војната имаат тенденција да ја мешаат војната со војување: второто е подложно на постојани промени, првото не е.

В) Во одбраната на релевантноста на политичката филозофија на Клаузевиц го истакнуваме и ставот на генерал сер Руперт Смит кој вели дека во денешната војна војуваат цивили, односно, војната е меѓу луѓе. Целта на употребата на воената сила е да се влијае на намерата на ^уѓето. Затоа и тој не може да се согласи кога се негира Клаузевиц, а и неговото тројство како неважно, затоа што искуствата од националните и меѓународните конфликти покажа дека без трите елементи - држава, војска и народ - не може да се изведе успешна воена операција. Тројството на Клаузевиц на држава, армија и луѓе е полезно средство со кое се анализираат целта и активностите на актерите иако тие понекогаш не се држава. Дури и недржавните актери без форма, зависат и се поврзани со луѓе/народ, кои ќе имаат (организација на) вооружена сила од некаков вид и ќе имаат некаква политичка насока за употреба на силата. И во ваков амбиент, мора да се помести фокусот од деструкцијата кон комуникацијата, чија цел ќе биде да се вдијае на волјата на луѓето. Тогаш водените операции мора да се спроведат под нарацијата на будните мас-медиуми и на таков начин да се вдијае на зависноста на настаните. Исто така, воените сили мора да се користат во соодветна легална рамка и да не оперираат надвор од законот. (Smith, 2005: 277, 303, 379).

\section{3. Кудтурен, правен и политички пристап на дефинирање на војната}

Кој било од погоренаведените филозофски пристапи да се одбере за да се разбере војувањето, ќе ја доведе анализата во насока спротивна на другите. Во меѓународните односи и студиите по безбедност војувањето се 
дефинира на начини кои ги нагласуваат културните, правните и политичките димензии.

Културен пристап: војувањето изгледа раздично и има поинакво значење, зависно од тоа каде и кога во историјата се врши анализа. Војната „секогаш е израз на култура, честопати детерминирана од културните форми, во некои општества е самата култура“ (Кеegan 1994: 12). Она што ние припадниците на една култура го дефинираме како чин на војување можеби не се поклопува со тоа како на истото тоа нешто гледаат припадниците на друга култура.

Како можеме да ја проучуваме модерната војна преку леќата на културата? Раздични армии се бореле на раздични начини од причини што не изгледаат многу рационално без да се земе предвид културниот контекст. ${ }^{4}$ Кога ќе се судрат раздични културни системи, резултатите може да бидат поразителни за едната страна сѐ додека таа страна не се приспособи ${ }^{5}$ К Културата е небулозен поим кој секогаш се менува; би било одлично да може да се зборува за единствена американска култура или за непроменлива арапска, но за жал, светот е покомплициран од тоа. Промените во културата во рамките на истото општество може да доведат до драматични резултати на бојното поле, како на пример масовната регрутација во минатото ${ }^{6}$. Ако не препознаеме како културата вдијае врз тоа зошто луѓето се борат, нема да можеме да ги препознаеме војните што доагаат сѐ додека не биде предоцна. И, ако не видиме како културите го оформуваат начинот на кој дуѓето се борат, нема да можеме да ги добиваме тие војни кога тие ќе дојдат.

Правен пристап. Општоприфатеното гледиште е дека војната е отворен и прогласен судир меѓу вооружените сиди на две или повеќе др-

\footnotetext{
${ }^{4}$ Ритуализираната племенска војна на Нова Гвинеја во дваесеттиот век за нас повеќе дичи на играта од училиште - избегни ја топката - отколку на битка, но веројатно ќе им била многу позната на микенските Грци од Илијада.

5 Така на пример при првичната инвазија на Монголците во Јапонија во 1274 година, самураите ги предизвикале напаѓачите на единствена борба, за со катастрофални резултати да откријат дека Монголите не ја делат нивната идеја за тоа како (достоинствено и со чест) би требало да се води битка.

${ }_{6}^{6}$ Така на пример, културната смена создадена од француските револуционерни идеали ѝ овозможила на Франција масовно да мобилизира масовна граѓанска армија од регрути; повикувајќи се на раздичните културни идеали на традиционадниот авторитет, за раздика од другите европски монархии кои не можеле да ги мобилизираат своите поданици на ист начин. Резултатот бил успехот Французите да ги спречат комбинираните сили на другите европски сили, па дури и под Наполеон да ги поразат сѐ додека овие другите не усвојат слични реформи. Ако не разбираме дека политичката култура вдијае на борбата против војната, ќе се збуневме зошто Франција, која со векови се борела да постигне хегемонија во Европа, одеднаш била во можност да го стори тоа. Слично на тоа, не би можеде да разбереме зошто ИСИС користи самоубиствен бомбашки напад, а Курдите не, или како Русија успеа да го поддржи сирискиот режим.
} 
жави или нации. Правнички, војната се дефинира како „легален услов кој допушта две или повеќе непријателски групи да спроведат конфдикт со вооружени сили“ (Wright 1983, 7). Јасно е дека во ова гледиште, војната се раздикува од мирот бидејќи е состојба на легален натпревар со воени средства. Но тоа не значи дека војната е синоним за остварување воен судир. Страните можат да бидат легално во состојба на војна, но без прекумерно насилство помеѓу нив. ${ }^{7}$ Војната не е само дејство, туку состојба или услов, во кој за народите се вели дека војуваат не само кога нивните армии се ангажирани, односно да бидат во самиот чин на судир, туку и кога, тие имаат какво било прашање на полемика или спор кој постои меѓу нив за што тие се решени да го одлучат со употреба на сила и јавно прогласиле, или со своите акти и нивната одлучност тоа да го решат. За национадните војни се вели дека се напаѓачки или одбранбени. Војната е напаѓачка од страна на таа влада која го прави првиот чин на насилство; таа е одбранбена од страна на таа влада што ја прима таквата активност; но многу е тешко да се каже кој е првиот чин на насилство. Ако некоја нација се гледа себеси загрозена од напад, нејзиниот прв чин на насилство за да спречи таков напад, ќе се смета за одбранбен. Бидејќи меѓународната правна рамка се дефинира согласно државите, анализирањето на војната само преку правната призма не се однесува на вооружените конфликти кога завојуваните не се држави иди кога владата на одредена држава ги смета активностите на домашните противници за криминална активност.

Тука се поставува прашањето дали војната и понатаму егзистира во очите на меѓународното право?! Во фактичка смисла на непријателства кои вклучуваат употреба на вооружена сила помеѓу државите, војната и понатаму постои и со тоа постојат и правила на меѓународното право кои ја регулираат. Но помалку очигледно е сепак, дали војната продолжува да постои како легадна состојба, творба која по автоматизам произведува одредени правни последици како за завојуваните страни, така и за други држави. Иако имаше голем број на случаи на непријателства по Втората светска војна, од кои некои и на високо рамниште, сепак, немаше формално прогласување војна и само неколку од тие конфликти беа класифицирани како „војна“. Но, тоа не значи дека едноставно „денес поимот војна е немодерен“. Истражувањето на тековната значајност на концептот на војна вклучува прашања од суштинска важност за забраната за закана за употреба на сила или употребата на сила во член 2(4) од Повелбата во време на засилена волја за употреба на сила како инструмент на надворешната политика.

Политичкиот пристап е најпопуларен пристап кој ја дефинира војната како одреден тип на подитичка активност која вкдучува насилство. Сорел (1912) ја дефинира војната како „политички чин со кој државите, кои не можат да го приспособат спорот во врска со нивните обврски, права

7 Пример за тоа се односите помеѓу Северна и Јужна Кореја по сецесијата и непријателствата во 1953 година. 
или интереси, прибегнуваат кон вооружена сила за да одлучат која е посилна и затоа може да ја наметне својата волја на другата“. Според Хедли Бул $(1977,178)$, таа е организирано насилство од страна на подитички единици едни против други. Насилството не е војна ако не се води во името на подитичка единица, убивањето во војна се раздикува од убиство поради неговиот официјален карактер, симболичната одговорност на единицата која убива. Исто така, насилството спроведено во името на подитичка единица не е војна ако не е насочено против друга подитичка единица како во случајот со насилство на државата во егзекуција на криминалци или попречување на пиратите, бидејќи е насочено против поединци.

\section{Заклучок}

Во меѓународните односи и студиите по безбедност војувањето се дефинира на начини кои ги нагласуваат културните, правните и политичките димензии. Повеќето мислители за војната, имаат тенденција војувањето да го третираат како да е самостоен процес кој во крајна динија работи според сопствените закони. Теоријата за војна на Клаузевиц е обвинета за зголемена ирелевантност во разбирањето на современите форми на војување, како што се граѓанска војна и недржавни судири. Критиката на теоријата за војна на Клаузевиц е изградена врз основа на две лажни претпоставки: (1) дека Клаузевицијанската мисла е инхерентно државноцентрична и (2) дека промените во режимите на војување се еднакви на промените во природата на војната (т.е. војување наспроти војна). Критичарите го зедоа секундарното тројство на Клаузевиц (народот, војската, владата) како основен столб на Клаузевициевата теорија, притоа занемарувајќи го критично важното примарно тројство (страст, шанса, разум). Поборниците на новата школа за размислување за војната имаат тенденција да ја мешаат војната со војување: второто е подложно на постојани промени, првото не е.

Можноста нуклеарното оружје да падне во рацете на групи посветени на спроведување на терористички спектакди без некакви конкретни побарувања претставува исто така раскинување со традицијата на Клаузевиц. Концептот на наратив може да придонесе за политичко насилство и радикализација, нудејќи нови средства за понатамошен развој на клучните конструкции како што се идентитетот, емоциите и културата. 


\section{Питература:}

Adelman, J. (1985). Revolution, Armies and War. Boulder, Col.: Lynn Rienner.

Bull, Hedley. (1977). The Anarchial Society: A Study Order in World Politics. London, Macmillan.

Clausewitz, C. von. (1976). On War. In Howard, M. \& Paret, P., Trans. Eds., Princeton, NJ: Princeton University Press. (Original work published 1832).

Downing, B. (1992). The Military Revolution and Political Change, Princeton, NJ: Princeton University Press.

Gat, A. (1989). The Origins of Military Thought, Oxford; Oxford University Press. Handel, M.I. (2008). Who is afraid of Carl von Clausewitz?. In T.G. Mahnken, \& J.A. Maiolo (Eds.), Strategic Studies: A Reader (pp. 53-71). Abingdon, UK: Routledge.

Hills, Allice. (2004). Future war in Citties. London, Franc Cass.

Hirst, Paul. (2002). 'Another Century of Conflict? War and the international system in the $21^{\text {st }}$ century'. International Relations, 16(3), 327-342

International Crisis Group (ICG). (2006). In their Own Words: reading the Iraqi Insurgency (ICG, Middle East Report N0.50, 15 February).

Kaldor, Mary. (2007). New and Old Wars. Oxford, UK: Polity Books.

Keegan, John. (1994). A History of Warfare. London, Vintage Books.

Kurtz, L. (1992). 'War and Peace on the Sociological Agenda', in T. Halliday and M. Janowitz (eds) Sociology and It.s Publics, Chicago: University of Chicago Press.

Lonsdale, D.J. (2016). The study and theory of strategy. In D. Jordan, J.D. Kiras, D.J. Lonsdale, I. Speller, C. Tuck, \& C.D. Walton (Eds.), Understanding Modern Warfare (pp. 21-38). Cambridge, UK: Cambridge University Press.

Marwick, A. (1974). Warand Social Change in the Twentieth Century, London: Macmillan.

Pemberton Antony and Pauline G. M. Aarten. (2017). "Narrative in the Study of Victimological Processes in Terrorism and Political Violence: An Initial Exploration," Studies in Conflict \& Terrorism. doi.org/10.1080/105761 0X.2017.1311110.

Rapoport, Anatol. (1968). 'Introduction' in Carl von Clausewitz, On War ed. Anatol Rapoport. London, Penguin. Pp.11-80.

Schuurman, B. (2010). Clausewitz and the "New Wars" Scholars. Parameters, $40(1), 89-100$.

Shimko, K.L. (2010). The Iraq wars and America's military revolution. New York, NY: Cambridge University Press.

Smith, H. (ed.) (1986). War and Social Change. Manchester: Manchester University Press.

Smith, Rupert. (2005). The Utility of Force. London, Allen Lane. 
Sorel, G. (1912). Réflections sur la violence. Rivière, Paris.

Strachan, H.F.A. (2014). The Direction of War. Cambridge, UK: Cambridge University Press.

Van Creveld, Martin. (1983). Fighting Power. London: Arms \& Armour Press.

Van Creveld, Martin. (1991). On Future War. London, UK: Brassey's.

Williams, P.D. (2013). War. In P.D. Williams (Ed.), Security Studies (pp. 187-206). Oxon, UK: Routledge Publishing.

Wright, Quincy. (1983). A Study of war. Chicago, IL Univesrity of Chicago Press, $2^{\text {nd }}$ edn. First published 1942. 
